Omni-Akuatika Special Issue $3^{\text {rd }}$ Kripik SCiFiMaS 2020: $71-77$
ISSN: 1858-3873 print / 2476-9347 online
Research Article
journal homepage: http://ojs.omniakuatika.net

\title{
Sediment Porosity Investigation of Tidal Zone in Teluk Penyu Cilacap, Indonesia
}

\author{
Florencius Eko Dwi Haryono*, Hydian Suripto, Mukti Trenggono \\ Marine Science Program, Fisheries and Marine Science Faculty, Jenderal Soedirman University, Purwokerto, \\ Indonesia \\ *Coresponding author: marine_2807@yahoo.com
}

Received 20 November 2019; Accepted 1 October 2020; Available online 31 December 2020

\begin{abstract}
The sediment fraction is the grain size, sorting and composition of the sediment, while sediment porosity is the ratio of the volume of the cavity in total volume. The cavity in marine sediment is a habitat of decomposing organisms. The research aimed to analyze the relationship between the fraction and porosity of tidal zone sediments in coastal of Teluk Penyu Cilacap. This survey method used sediment core samplers, sediments fractions used sieve method and the porosity used method of Reeve (1986), and analysis used software SPSS20. The results showed that tidal zone sediments in coastal of Teluk Penyu Cilacap were dominated by the fine sand with percentage when high water was higher than low water. Based on mean size diameter, sediment near Serayu river was found medium sand and far was fine sand. Based on linear regression, the relation between sediment fraction and porosity at high water and low water was obtained very weak, but when low water was found in opposite condition to the high water, that the greater of sediment diameter was smaller of porosity. High porosity indicates a wider space between the sediments and allows more decomposing organisms. It is important to consider the results of the clearing of organic matter which affects to fish resources in coastal waters.
\end{abstract}

Keywords: sediment fractions, porosity, teluk penyu

\begin{abstract}
ABSTRAK
Fraksi sedimen adalah ukuran butiran, penyortiran, dan komposisi, sedangkan porositas sedimen adalah rasio volume rongga dalam volume total. Ruang antara partikel sedimen laut sebagai habitat organisme pengurai. Penelitian ini bertujuan untuk menganalisis hubungan antara fraksi terhadap porositas sedimen pada zona pasang surut di Pantai Teluk Penyu Cilacap. Metode survei ini menggunakan sedimen inti sampel, fraksi sedimen menggunakan metode saringan dan porositas menggunakan metode Reeve (1986), dan data dianalisis menggunakan perangkat lunak SPSS20. Hasil penelitian menunjukkan bahwa sedimen zona pasang surut di pesisir Teluk Penyu Cilacap didominasi oleh pasir halus dengan persentase ketika air tinggi lebih tinggi daripada air rendah. Berdasarkan ukuran rata-rata diameter, sedimen dekat sungai Serayu ditemukan pasir sedang dan jauh adalah pasir halus. Berdasarkan regresi linier, hubungan antara fraksi sedimen dan porositas pada air tinggi dan air rendah diperoleh sangat lemah, tetapi ketika air rendah ditemukan dalam kondisi yang berlawanan dengan air tinggi, bahwa semakin besar diameter sedimen semakin kecil porositasnya. Porositas yang tinggi mengindikasikan ruang atara sedimen yang lebih luas dan memungkinkan organisme pengurai lebih banyak, penting untuk mempertimbangkan hasil perombakan bahan organik yang berpengaruh terhadap sumberdaya ikan di perairan pantai.
\end{abstract}

Kata kunci: fraksi sedimen, porositas, teluk penyu

\section{Introduction}

Characteristic of wave and result of variation longshore sediment transport is played by climate change (Dastgheib, et al., 2016). Local,regional and global-scale climate variability mode are impact to inter-annual fluctuation (Manta et al., 2016). Beach is 
known as meeting place of sea and land and dynamic processes of wind, wave and tide impacted to continue constantly changing of those places (CERS 1984). Another side of gravity of the moon and sun have caused tidal currents and impact the process of sediment dispersal as role of the tide. (Akter et al., 2016). Low-lying environment as a fundamental role in the development is played too by sea-level rise (Vankoningsveld et al., 2008). The coastal vulnerability is highly along the coast as erosion (Boruff at. al., 2005). The changes of coastal morphology are affected by ocean current and waves (Duxbury et al., 2002).

A fundamental property of marine sediment is porosity and can be easily determined based on wet bulk density (Curry,et al., 2010). Porosity is used as a basic parameter in simulation studies for predicting reservoir quality and an important petrophysical characteristic (Van Greet et al., 2003). The large independence of the deviation stress, and large independence of the nature of the stress field acting on the basin (compressional, extensional etc.) is a strong impact to the change of porosity (Jones and Addis,1985). Coastal porous structure is related to characteristic of resistance force in porous media (Chen et al., 2002). Mixture of sediment is systematically changed by grain sizes and volume fraction of sediment (Kamann et al., 2007). Water content in sediment is related to the increase in porosity (Droppo et al., 2000). Estuary system as part of coastal effectively traps particles, originating from the waters hed. The dominant particles are fluvial sources, particles of a more oceanic provenance (Alexander and Windom, 2017).

Upper-slope to deep marine sediments are a function of both burial depth and lithology. Kominz et al. (2011) was found overall porosity range from 4 to $94 \%$ and exponential trend towards decreasing porosity with depth. Curry et al. (2010) stated Sampling methods of marine sands is applying core to analyze in situ porosity and was found average porosity of sand $37.7 \%$ to $46.3 \%$. The aim of the research was analyze the relationship between the sediment fraction and porosity of sediments at tidal zone during high tide and low tide at Teluk Penyu, Cilacap coast, Indonesia.

\section{Materials and Method}

\subsection{Research procedure}

Sediments are collected at 8 stations of Cilacap coast using $2 \times 30$ inch by sediment core samplers and taken 3 times in each station. Fraction of sediments is analyzed based on sieve method and the classification of sediment fraction based on Holme and McIntyre (1971). Statistical analysis of sediment based on mean size (Blott and Pye,2001. The relationships between porosity and median of sediment fraction is analyzed by excel software 2003.

\subsection{Data analysis}

The porosity is analyzed based on Reeve [1986] and the relation between sediment fractions and sediment porosity is analyzed based on software SPSS 20.

\subsection{Research site}

The research sites at the coastal of Teluk Penyu Cilacap. Indonesia. Distance of each site is $12 \mathrm{~km}$ of the $40 \mathrm{~km}$ of coastal length of Teluk Penyu coast. Station number 1 is located at southern of the coast and station number 8 is at eastern of the coast (Figure 1).

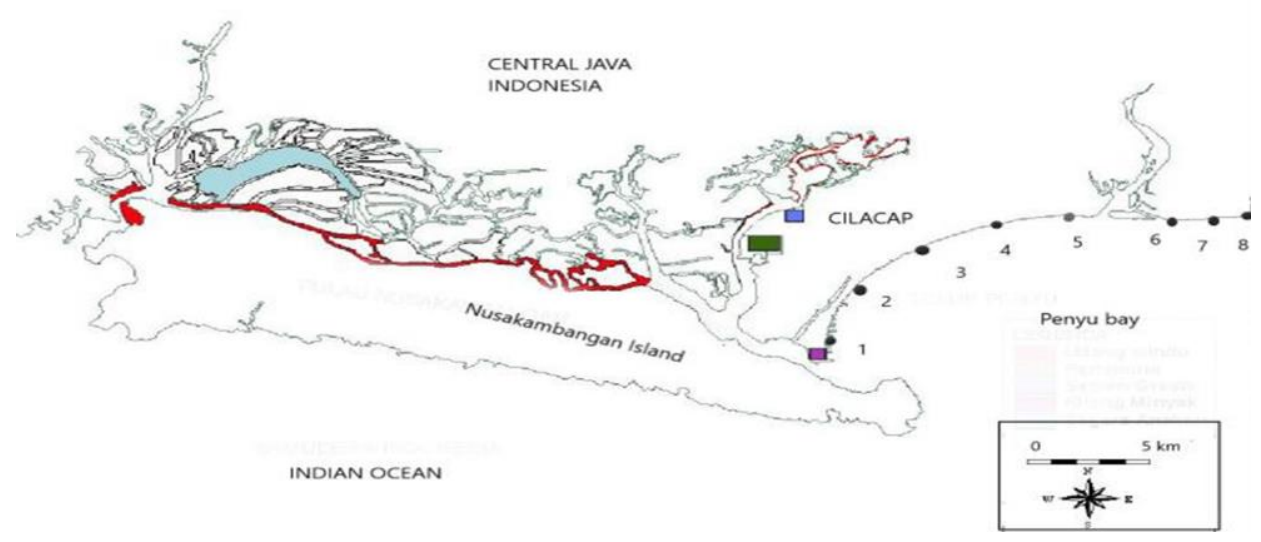

Figure 1. Research site stations of Teluk Penyu, Cilacap-Indonesia 


\section{Result and Discussion}

\subsection{Sediment fraction}

Tidal area is the part of integration location of sea water, land and the air. The coastal as a dynamic area is influenced by tidal pattern, wave and climate. Sediment from upland is deposited by river current to the coast and those sediments are distributed by tidal pattern, wave and wind driven current. A shorter of sediment diameter is distributed long shore of the coast or shallow water and to deep seas.

Cilacap coastal water is bordered and open access to Indian ocean. The oceanic, climate and tidal patterns are influence the waters, and at other side, the sediment is accumulated by all of the patterns. Tidal pattern at southern Java waters is categorized as semi diurnal type that produced two of high and two of low water daily.

The dynamic of sediment fraction transport is more were impacted by wave and tidal force. The mean size $[\mathrm{mm}]$ of sediment in tidal area at Cilacap coast when high and low water were found two of sediment classification, namely fine sand and medium sand.

The range of diameter of sediment when high water was obtained lower than low water and based on the average sediment's diameter were impacted by wave and tidal force. The mean size [mm] of sediment in tidal area at Cilacap coast when high and low water were found two classification of sediment, namely fine sand and medium sand (Table 1). The range of diameter of sediment when high water was obtained lower than low water and based on the average sediment's diameter was classified as fine sediment. The sediment diameter when low water was classified as medium sand.

The range of median size of sediment diameter during high and low water were found between 0 to 5.27, and during high water, the average of median of sediment diameter was obtained $1.09 \mathrm{~mm}$. The value of the median sediment diameter was indicated that the classification as very coarse sand (Table 2). The range of median when low water was found differs to the high water, and the mean of median was obtained $0.305 \mathrm{~mm}$, the sediment was classified as medium sand with the range from 0.239 to $0.470 \mathrm{~mm}$.

The dynamic of sediment in Cilacap coast was influenced by sediment supply from Serayu river at the middle coast and Bodo river at the Eastern coast. The existence of the river estuary at the Eastern part of the coast of Teluk Penyu waters, and the existence of Segara Anakan Lagoon at Southern part were impacted of different of sediment fraction, which sediment from Segara Anakan waters was found smaller than sediment from Serayu river. The Eastern of the lagoon is estuaries of some rivers, namely Sapuregel, Donan rivers that supplies heavy sediment from upland and the sediment was dominated by mud.

The sediment from Serayu river at the middle coast was dominated by sand and Bodo river at the eastern coast was supply mud sediment. Tidal and wave patterns were accumulate the sediment from Southern, middle and Eastern coast as mixtures sediment. The distribution of median and mean size of sediment diameter in this research were influenced by the existence of the rivers, that Serayu river [Station 5 and 6] at the middle coast was obtained longer of those sediments diameter from Eastern and Southern of Penyu bay coast during high and low waters (Figure 2).

Tidal pattern was produce current a long the coast and was impact to sediment distribution. Based on the sediment diameter measurement (mean size and median) the direction of tidal current in time of low to high

Tabel 1. Mean size [mm] sediment in tidal area each station

\begin{tabular}{ccccc}
\hline \multirow{2}{*}{ Station } & \multicolumn{2}{c}{ High Water } & \multicolumn{2}{c}{ Low Water } \\
\cline { 2 - 5 } & $\begin{array}{c}\text { Mean } \\
\text { Size }\end{array}$ & $\begin{array}{c}\text { Sediment } \\
\text { Class }\end{array}$ & $\begin{array}{c}\text { Mean } \\
\text { Size }\end{array}$ & Sediment Class \\
\hline 1 & 0.197 & Fine sand & 0.395 & Medium sand \\
2 & 0.272 & Fine sand & 0.239 & Fine sand \\
3 & 0.238 & Fine sand & 0.266 & Medium sand \\
4 & 0.274 & Med-sand & 0.270 & Medium sand \\
5 & 0.409 & Med-sand & 0.294 & Medium sand \\
6 & 0.321 & Med-sand & 0.470 & Medium sand \\
7 & 0.262 & Med-sand & 0.260 & Medium sand \\
8 & 0.239 & Fine sand & 0.242 & Fine sand \\
\hline Mean & 0.277 & Fine sand & 0.305 & Med-sand \\
\hline
\end{tabular}


Table 2. Median sediment fraction [mm] and sediment classification when high and low water at stations, Cilacap coast.

\begin{tabular}{ccccc}
\hline Station & \multicolumn{5}{c}{ Median Sediment Diameter [mm] } \\
\cline { 2 - 5 } & $\begin{array}{c}\text { High } \\
\text { Water }\end{array}$ & $\begin{array}{c}\text { Sediment } \\
\text { Classification }\end{array}$ & $\begin{array}{c}\text { Low } \\
\text { Water }\end{array}$ & $\begin{array}{c}\text { Sediment } \\
\text { Classification }\end{array}$ \\
\hline 1 & 0.3 & Medium sand & 6 & Pebble \\
2 & 0.47 & Medium sand & 0.57 & Coarse sand \\
3 & 0.1 & Fine sand & 0.07 & Very fine sand \\
4 & 0.6 & Coarse sand & 0 & Clay \\
5 & 5.27 & Pebble & 1.43 & Very coarse sand \\
6 & 2 & Very coarse sand & 5.13 & Pebble \\
7 & 0 & Clay & 0 & Clay \\
8 & 0 & Clay & 0 & Clay \\
$x$ & 1.09 & Very coarse sand & 1.65 & Very coarse sand \\
\hline
\end{tabular}

water, the current was flow from Eastern to Southern. The tidal current direction to Southern was influence the mean size sediment diameter in each station of southern part of the coast, station number 1 was located at the edge of Southern part of Panyu bay coast and station 8 at the edge of Eastern part of that coast. The influence of the current to the sediment was distributed from East to Southern part of the coast during high water.Current from tidal pattern was influence the sediment distribution, which was based on the measurement of mean size and median of sediment diameter during high and low water, it was opposite impact by tidal current during low to high tide. The direction of current during high to low water from South to East. Those tidal current direction was impact the mean size sediment diameter in each station. During the current flow from low to high water, the sediment was distributed from estuary of Serayu river to coast and it was spread to East coast. Subsequently, the sediment was distributed from station 1 to 8 by tidal current when high to low water.

\subsection{Porosity}

Porosity is percentage of ratio between weight and specific gravity of sediment (Reeve, 1986). Wave has a significant effect to porosity (Mai et al. 2019). Coastal porous structure is related to the characteristics of resistance force in porous media (Chen et al. 2002). At coastal the influence of sand erosion and deposition of sediment is a significant difference at backwash area of the coast (Packwood, 1983).

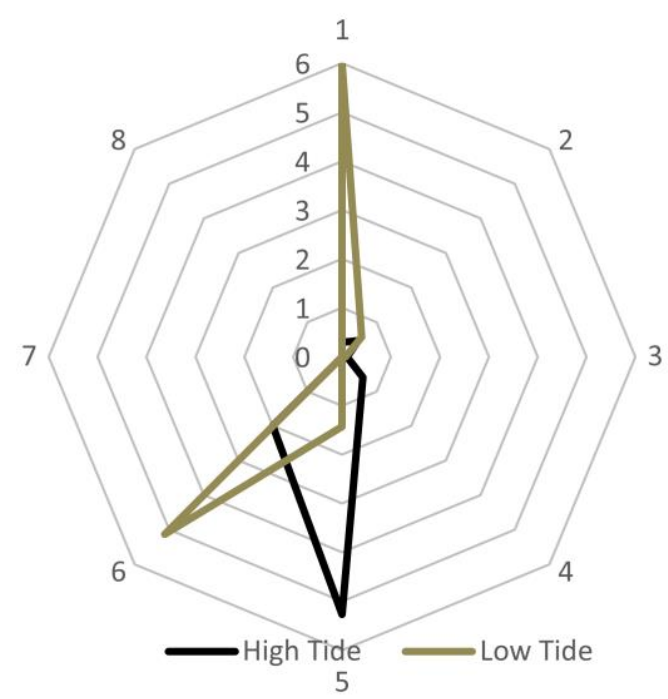

Figure 2. Median sediment fraction $(\mathrm{mm})$ when high and low water at Cilacap coast. 
Table 3. Porosity sediment [\%] when high and low waters at stations, Cilacap coast.

\begin{tabular}{cccc}
\hline \multicolumn{4}{c}{ Porosity (\%) } \\
\hline Station & Hight Water & Low Water & Mean \\
\hline 1 & 62.93 & 64.67 & 63.8 \\
2 & 67.13 & 67.13 & 67.13 \\
3 & 66.90 & 67.07 & 66.98 \\
4 & 67.27 & 67.33 & 67.30 \\
5 & 65.07 & 67.20 & 66.13 \\
6 & 60.53 & 61.40 & 60.96 \\
7 & 60.63 & 60.67 & 60.65 \\
8 & 60.53 & 62.93 & 61.73 \\
\hline Mean & 63.87 & 64.80 & 63.46 \\
sd & 3.197 & 3.1979 & \\
\hline
\end{tabular}

The range of porosity of sediment in tidal area at the coast of Teluk Penyu, Cilacap was found between 60.53 to $67.27 \%$ at the time during high water and the average was obtained $63.87 \%$. The porosity of sediment during low water was obtained in range between 60.67 to $67.20 \%$ and an average was $64.80 \%$ (Table 3). Porosity of sediment became higher during low water than high water, the condition was expected as a result of the integration force of tidal current and wave. Those force was transport the sediment from back shore during high water to the tidal area. The result of the process was impact to the diameter of the sediment on the back shore longer than in the deep-sea water.

\subsection{Relation of Porosity to Sediment Fraction during Tidal Pattern}

Relation between porosity and median of sediment fraction during high water was found $6.6 \%$, negative relation and the value was a very low relation (Figure 3 ) bellow : Sea water level becomes higher at the moment of high water and coast area is flooded. The force of tidal current and wave are distribute the coast sediment to the tidal area and to deep water. On the other side, wave force is transport the

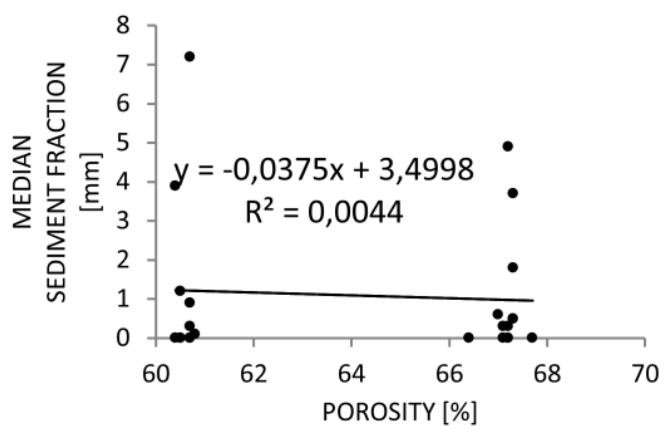

Figure 3. Relationship between porosity and median sediment fraction during high water at Cilacap coast. sediment from shallow sea water while there is a height of wave is equal to the depth of sea water. The condition is result to the tidal zone as a burning area of sediment as impact by wave and tide forces.

Relation between porosity and median of sediment fraction during low water was obtained higher than during high water, namely $33.03 \%$ for low water and the relation value was categorized as low relation. The higher value of relation between porosity and median sediment fraction during low water was expected to be an impact of wave force at the moment of low water to the sediment from the back shore that is transported to tidal zone. The simple linear regression was found negative equation, that the value was indicated the increase of median sediment diameter was followed by the decrease of porosity (opposite interaction).

Sea bed of tidal zone is a dynamic area from the impact of tidal patern, wind driven current, climate variability and each coast has specific morphology as impact of that climate variation. The research has been done during transition season (October 2019). The effect of the climate, especially during transition season, on the beach morphology of sea bed slope at tidal zone becomes ramp and steep

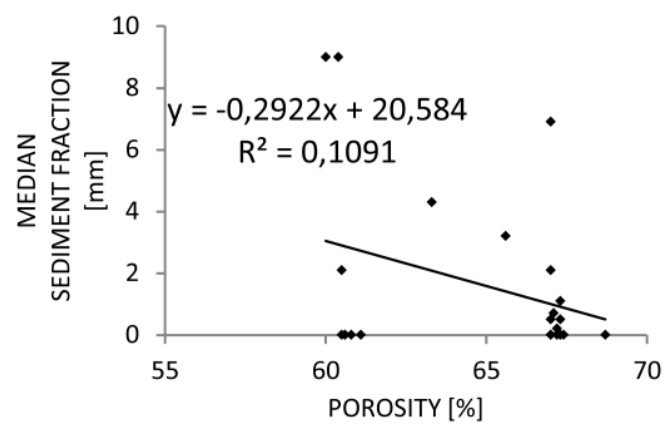

Figure 4. Relationship between porosity and median sediment fraction during low water at Cilacap coast. 
during wet season, especially at tidal zone for Southern Java coast. The development of porosity was found asymmetric across the mixing zone (Sanford and Konikow, 1989). The tidal zone is the mixing burring area of sediment.

Characteristic of porous structure of sediment is same to coefficient of permeability and turbulent that tends to stabilize. The characteristics of resistance force in porous media to improve related applications on coastal porous structures (Chen et al., 2002). The relation between the percentage of sand and loading capacity of the sediment was indicate that serious cliff is to be occur when the percentage of sand sediment mix exceeds a critical value (She et al., 2006).

\section{Conclusion}

Tidal zone sediments in coastal of Teluk Penyu Cilacap were dominated by the fine sand with the percentage of $77.34 \%$ for high water and $75.60 \%$ for low water. The mean size of sediment diameter in the station $1,2,3$, and 8 was found fine sand and in stations 4,5 , 6 , and 7 were obtained medium sand. The relationship between the sediment fraction and porosity during high water and low water were obtained very weak, but the relationship at the moment of low water was found in opposite condition to the high water, when low water was found greater of sediment size and porosity.

\section{References}

Akter, J., Sarker, M. H., Popescu, I. and Roelvink, D. 2016. Evolution of the Bengal Delta and its prevailing processes. Journal of Coastal Research: 32(5): 12121226.

Alexander, C. R. and Windom, H. L. 2017. Material mobilization and transport in the Anadyr River-Estuarine system, eastern Siberia. Journal of Coastal Research 33(3): 548-563.

Boruff, B. J., Emrich, C. and Cutter, S. L. 2005. Erosion hazard vulnerability of US coastal counties. Journalof Coastal Research 21(5): 932-942.

Chen,Chen-Yuan., Lee,Chung-Pan and Chen, C. W. 2002. On the Permeability Inside the Grainulas Media. Journal of Marine Science and Technology 10(2): 136-145.
Curry, C. W., Bennett, R. H., Hulbert, M. H., Curry, K. J. and Faas, R. W. 2010. Comparative Study of Sand Porosity and a Technique for Determining Porosity of Undisturbed Marine Sediment. Marine Georesources \& Geotechnology 22(4): 231-252.

Dastgheib, A., Reyns, J., Thammasittirong, S., Weesakul, S., Thatcher, M. and Ranasinghe, R. 2016. Variations in the Wave Climate and Sediment Transport Due to Climate Change along the Coast of Vietnam. J. Mar. Sci. Eng. 4(4): 86.

Droppo, I. G., Walling, D. E. and Ongley, E. D. 2000. The influence of floe size, density and porosity on sediment and contaminant transport. The Role of Erosion and Sediment Transport in Nutrient and Contaminant Transfer (Proceedings of a symposium held at Waterloo, Canada, July 2000). IAHS Publ. no. $263,2000.141$

Evans, R. L., Law, L. K., St. Louis, B., Cheesman, S. and Sananikone, K. 1999. The shallow porosity structure of the Eel shelf, northern California: results of a towed electromagnetic survey. Marine Geology 154:211-226

Forster, S., Bobertz, B. and Bohling, B. 2003. Permeability of Sands in the Coastal Areas of the Southern Baltic Sea: Mapping a Grain-size Related Sediment Property.Aquatic Geochemistry 9(3): 171190.

Jensen, B. 2014. Wave Interaction with Porous Coastal Structures. Technical University of Denmark.

Jones, M. E. and Addis, M. A. 1985. On changes in porosity and volume during burial of argillaceous sediments. Marine and Petroleum Geology 2(3): 247-253.

Kamann, P. J., Ritzi, R.W., Dominic, D. F. and Conrad, C. 2007. Porosity and Permeability in Sediment Mixtures Reply. Ground Water 45(4): 429-38.

Kominz, M. A., Patterson, K. and Odette, D. 2011. Porosity in Slope and Deep Marine Sediments. Lithology Dependence of Porosity in Slope and Deep Marine Sediments. Journal of Sedimentary Research 81(10): 730-742

Mai, T., Dao, T., Ngo, A. and Mai, C. 2019. Porosity Effects on Wave Transmission 
Through a Bamboo Fence. International Conference on Asian and Pacific Coasts. APAC 2019:1413-1418

Manta, G.; Barreiro, M.; Ortega, L. and Defeo, O., 2017. The effect of climate variability on the abundance of the sandy beach clam (Mesodesma mactroides) in the southwestern Atlantic. Journal of Coastal Research 33(3): 531-536.

Missimer, T. M. and Lopez, O. M. 2018. Laboratory Measurement of Total Porosity in Unconsolidated Quartz Sand by Two Integrated Methods. J Geol Geophys 2018 7: 5

Packwood, A. R. 1983. The influence of beach porosity on wave uprush and backwash. Coastal Engineering 7(1): 29-40.

Sanford, W, E. and Konikow, L. F. 1989. Porosity development in coastal carbonate aquifers. GEOLOGY 17: 249252.

She, K., Horn, D. P and Canning, P. 2006. Porosity and Hydraulic Conductivity of Mixed Sand-Gravel Sediment. Conference: Flood and Coastal Risk Management.
Scott, T., G. Masselink, P. Russell. 2011. Morphodynamic Characteristics and Classification of Beaches in England and Wales. Marine geology. School of Marine Science and Engineering, University of Plymouth, Drake Circus, Plymouth, United Kingdom 10: 1-20.

Reeve, M.J. 1986. Water Retention, Porosity and Composition Interrealationships of Alluvial Soils in Mid Hawke's Bay and Their Relevance in Irrigation Planning. New Zealand Journal of Agricultural Research 29(3): 457-468

Vankoningsveld, M., Mulder, J. P. M., Stive, M. J. F., Vandervalk, L. and Vanderweck, A.W. 2008. Living with sea-level rise and climate change: a case study of the Netherlands. Journal of Coastal Research 24(2): 367-379.

Van Geet, M., Lagrou, D. and Swennen, R. 2003. Porosity measurements of sedimentary rocks by means of microfocus X-ray computed tomography $(\mu \mathrm{CT})$. Geological Society, London. Special Publications 215: $\quad$ 51-60 